\title{
Livestock production and marketing for small emerging farmers in South Africa and Kenya: comparative lessons
}

Mbatha, C.N. ${ }^{1}$

Corresponding Author: C.N. Mbatha. Email: nhlanhla.mbatha@gmail.com

\section{ABSTRACT}

Poor production methods and limited market access are some of the challenges that prevent small African farmers from developing. In cattle farming, poor grazing practices and a lack of vaccination produce poor quality animals. Limited information, poor infrastructure, cultural issues and other factors, lead to low participation levels of these farmers in livestock markets. This study explored the prevalence of these challenges in two geographical locations of two African countries (South Africa and Kenya) with the intention to identify possible cross lessons for developing small rural farmers. Ethnographic and case study methods were used to collect and analyse data in two provinces (one in each country) where cattle farming by small rural farmers is predominant. From the two countries, three cases of distinguishable cattle production and marketing challenges were identified. Firstly, rural South African (SA) small farmers are generally faced with high production and marketing challenges, which prevent them from developing into successful commercial farmers. Secondly, Kenyan small rural farmers face similar production challenges as those faced by their SA counterparts, but perform better at marketing their animals, although they still face a lot of structural marketing issues, with brokers controlling the market to the disadvantage of farmers. Thirdly, the study identified a case of rural Black SA farmers who are being assisted through a research project in the Eastern Cape Province that embraces a more holistic environmental approach to rural development to overcome most production and marketing challenges. Given the successes of the holistic view, this study concludes that the environmental approach presents the best case lessons for replication across SA in developing small African farmers. It is argued that the replication of lessons across SA would require central coordination by a government agency. The national agricultural extension office (one of whose mandates is to work directly with farmers for their development) would be most appropriate for this coordination role.

Keywords: Small farmers, livestock, production, marketing, extension office

\section{INTRODUCTION}

Many studies identify issues including, limited access to markets and capital, lack of technical and marketing skills, among the important explanations of why projects to develop small

\footnotetext{
${ }^{1}$ Director: Institute of Social and Economic Research (ISER), Rhodes University, P.O. Box 94, Makhanda (Grahamstown) 6140, South Africa, Tel. 046603 8111. Email: nhlanhla.mbatha@ gmail.com ORCID: 00000002-6990-6455
} 
African farmers have failed in South Africa (SA) (e.g. Van Koppen., Tapela, \& Mapedza, 2018). Studies looking specifically at business problems in livestock farming by farmers in communal areas have identified issues, including lack of market information, poor infrastructure, poor livestock quality ${ }^{2}$, cultural issues, etc., (e.g. Coetzee, L., Montshwe, B.D. \& Jooste A., 2005; Musemwa, 2008; Mmbengwa, V.M., Nyhondo, B., Lindikaya, M., Ngethu, X. \& van Schalkwyk, H. 2015.) as interlinked marketing challenges in these settings.

This paper explores and compares how some of the common challenges in cattle production and market access have, to varying degrees, been overcome in Kenya and in SA. Firstly, from different sources the paper presents a range of issues that are facing small rural farmers in livestock value chains (i.e. from production to marketing) in SA. It is later illustrated how some of the issues are common for both countries, especially with respect to livestock production. Secondly and in terms of marketing, Kenyan small farmers were found to be more advanced than their SA counterparts in terms of their level of participation in formal markets. However, the higher level of participation of these Kenyan farmers in livestock markets has other challenges, which come mainly from the farmers' lack of resources including infrastructure to transport animals to markets. Historically the lack of these resources has allowed an emergence of powerful traders who control markets to the detriment of poorly resourced farmers. This study concludes that the phenomenon of trader market control has to be avoided in SA as market access for farmers is improved. Finally, a model through which many of the documented challenges in livestock farming for both countries could be avoided or reduced came from the lessons learnt in a small project found in the Eastern Cape Province (ECP) of SA. This project has a holistic environmental approach to rural development, with rangeland restoration as one of its objectives. Given most of the issues documented in SA and Kenya it is argued that the project's holistic approach to rural development provides the best lessons found for both SA and Kenyan small farmers and rural communities. The study proposes that the lessons from this model could be replicated in other parts of SA by coordination through the national extension office. In the ECP project, the local agricultural extension office already forms part of important stakeholders on the ground. Among these stakeholders, the agricultural extension office has the required national footprint and shares many of the developmental objectives of the project to promote the lessons across the country.

The paper outlines the problem in Section 2. Methods used for collection data are presented in Section 3 with theoretical framework. Specific production and marketing challenges for SA are presented in Section 4. Section 5 presents challenges in Kenya. The case of the MNP in the ECP is presented Section 6. A comparative discussion with recommendations are provided in Section 7. Section 8 is a summary.

\footnotetext{
${ }^{2}$ From issues like rangeland degradation and poor vaccination (see Luppnow, 2003 \& De Waal, 2004 in Coetzee et al., 2005)).
} 


\section{SMALL SCALE LIVESTOCK FARMING ISSUES IN SA}

Production and marketing challenges facing SA small livestock farmers have been documented by numerous studies in the last thirty five years (e.g. King, 1985; Jooste, 1996 \& 2005; Bailey et al., 1999 and USAID, 2003 in Coetzee et al., 2005; Musemwa L., Mushunje A., Chimonyo, M., Fraser G., Mapiye C. \& Muchenje V. 2008; Mmbengwa et al, 2015; etc). These farmers are mostly located in areas formerly known as homelands under the Apartheid system, including the former Transkei, Lebowa, etc. Mmbengwa et al (2015) reported that their herds are dominated mostly by crossbreeds $(72.4 \%)$, followed by Nguni cattle at $15.6 \%$. The challenges they face have remained mainly the same even though what seems like sensible policy suggestions have been proposed in literature over time. The challenges can be broadly grouped into two categories, namely, those faced in production and those in marketing. They remain in place even though more than a third of total livestock in the country is owned these small farmers (Jooste, 2001). This means that a big segment of the population is affected negatively by lack of improvements. For example, only $10 \%$ of the total herd is being marketed from communal areas, compared to $25 \%$ from commercial farmers. Findings from the ECP study on cattle marketing (Coetzee et al., 2005) indicate that the trends in the province are a microcosm of those experienced in the country (Musemwa et al., 2008). Communal livestock farmers in the province keep a combination of animals in their herds, most notably, cattle, sheep and goats, with the following population estimates:
a. 2706576 (Sheep)
b. 1832461 (Goats), and
c. 1781617 (Cattle)

Challenges in managing livestock and in improving businesses also stem from the fact that there are many more farmers who own smaller numbers of herds, as opposed to a fewer farmers owning bigger herds. In limited capacities of communal grazing areas this would lead to conflicts among livestock owners on land management issues. This has a direct negative impact on the health and number of Large Stock Units (LSU) ${ }^{3}$ raised per hectare of land. For example, Coetzee et al. (2005) reported that the stocking rate in communal areas was 1.56 hectares per LSU, where it should have been 7 hectares. Compared to total livestock numbers reported above, for healthier herds smaller LSUs numbers in the province for the same period were the following:
a. 451096 (Sheep - $16.7 \%$ of total)
b. 295558 (Goats - 16.1\%), and
c. 1484680 (Cattle $-83.3 \%)$

The lower LSU numbers illustrate the poor quality of livestock held in communal areas, especially for sheep and goats. The poor quality of stock owned by many farmers also increases

\footnotetext{
3 "A Large Stock Unit (LSU) is defined as the equivalent of an ox with a weight of 450kg and a weight gain of $500 \mathrm{~g}$ per day on grass pasture with a mean Digestible Energy (DE) concentration of 55\%" (Mokolobate, Scholtz, \& Calitz, 2017:17).
} 
transaction costs for buyers who spend more time searching for good quality stock from too many potential sellers. Hence many production challenges are intertwined with those in marketing and must be understood systematically. These problems contribute in varied ways in prohibiting market access by small livestock farmers whose cases are presented and analysed in this paper.

\section{METHODS FOR COLLECTING DATA FRAMEWORK FOR ANALYSIS}

With continuous reviews of literature, the research applied an institutional and ethnographic mode of constructing pattern models, which is holistic, systematic and evolutionary (Wilber \& Harrison (1978:73), in collecting and analysing data to tell a story without prescriptions (Oosthuizen, Meiring, Botha, Grove, Monkhei, \& Pretorius, 2005:71-72). Hodgson (1998:168) explains that in this mode, probabilities characterise the relational explanations of current and past patterns and trends of connected parts of a system. For instance, an event is explained by identifying its relational position in the pattern of change. The explanation of a cumulative causation (not prediction) is given the highest priority. The method "strives for a depth of understanding as an end in itself, not as an attempt to predict what may happen in the future, or to generalise (through some general law) to a universe" (Oosthuizen et al., 2005:72). To construct patterns for explanation the researcher is socialised into a system. The norms and traditions of the system are impressed upon them, e.g. the importance of ceremonies, dowry payment rituals, social status, etc.

Procedurally, the Kenyan and SA agricultural systems were divided into parts (e.g. farms, communities and markets) to identify themes that connect the parts to construct the systems. In 2018, more than 60 Kenyan farms were visited at their areas of work to observe and discuss their activities, successes and challenges using a semi structured set of questions on production and market related subjects.

Using Kenyan literature on geographical, economic indicators as well as previous studies on agricultural markets and livestock production in two different regions of Kenya (Lowlands and Highlands) were identified for surveying. The general questionnaire looked at production and marketing areas focusing on six broad themes; a) general demographics, b) type of farmer (e.g. sector), c) marketing strategies, d) access to physical resources, e) support structures, and f) returns to farming. The decision on the final themes were derived from the challenges documented in reviewed literature as facing smallholder farmers in Africa. The themes were discussed and accepted as the main areas of focus by a research group working in the area of land reform and associated challenges in different African countries. The initial survey was conducted in the warmer Lowlands of the Kilifi district focusing mainly on irrigating crop growers. From the lessons of the initial survey, the themes and questions were modified and adapted for farmers in accessible towns located in the Highland regions where many more livestock keepers could be found based on literature reviews. 
In the Highlands, agricultural markets in the towns of Eldoret and Cheptiret in the Rift Valley were visited for observations and discussions with traders at auction to identify recurring themes in relation to farmers that would explain the system and document in the form of a case study. In SA, discussions with stakeholders, including facilitators, organisers, community leaders, sellers, buyers, etc., in the ECP were carried out in 2018 and 2019, with follow up observations and further discussions at different types of auctions and meetings to construct an emerging system for recurring pattern themes for case study documentation.

\subsection{Some theoretical issues}

Conceptually, the challenges facing SA small farmers ${ }^{4}$ have been historically characterized as stemming from transactional costs and lack of information (e.g. Jooste, 1996 \& 2005; Bailey et al., 1999; Coetzee et al., 2005; Musemwa et al., 2008, etc.). The costs of putting up infrastructure to keep and transport livestock to markets, the poor state of roads and lack of information about when and how auctions operate and what quality is required are only some of the challenges facing small farmers that can be explained through basic economic theory. For these challenges, it may also be easier to propose possible interventions (e.g. that extension offices provide the required infrastructure and information to farmers) (see Coetzee et al., 2005 and Musemwa et al., 2008). There are, however, other sociological challenges that have been identified that are not easily explainable by orthodox economic theory such as information and transactional cost theories. For example, dealing with cultural motivations for keeping and using livestock is a challenge for market-oriented interventions. Figuring out ways to preserve important cultural practices that define community identities and traditional structures while promoting economic markets is harder for researchers and policy makers. This is partly because cultural practices are often hard to understand by external agents and in some cases cultural practices may conflict with market principles. This means that understanding these issues needs more nuanced interventions to be carefully orchestrated to have positive impacts. In this sense there are two self-reinforcing issues at play, namely, a) possible lack of theoretical explanations, and b) failure to implement (possibly inadequate) solutions by government agencies.

In new institutional economics, transactional and information costs are important as discussed historically by Ronald Coase (1937). His propositions proved important for institutionalists like North (1990; 1991 \& 1992), Hodgson (1998 \& 2006), etc. Coase (1998:73) argued that economists need not only think of themselves as having a box of tools to apply to some subject matter. As argued by Saleth (2004) for a general approach, researchers need to at least use; a) market-based theories from a market competition lens (e.g. North, 1992), b) evolutionary theories, which explain the emergence and dominance of traditions (e.g. Quiggin, 1988) and c) bargaining theories, which explain institutions in terms asymmetric powers (e.g. Ostrom, 1990). While there are basic elements of economic markets that affect small farmers, the farmers also operate under social conventions which may not support efficient market

\footnotetext{
${ }^{4}$ As well as Kenyan small farmers as illustrated in this paper.
} 
operations. They also deal with unevenly distributed governance powers of tradition and cultural practices. For example, the current use of land for purposes of grazing in many communal areas is governed by changing and competing communal land rules, with some adverse effects on the sustainability of land resources. Land erosion has been the result. With constraints on resources, there is a lot of bargaining with powers centralised in traditional leaders and some male figures in communities that female headed households must contend with.

At auctions, small farmers would find useful any information on how prices are determined based on the quality of livestock, number of competing sellers and bidders, etc. With respect to auctions, market-based theoretical explanations of operational processes may be helpful. The changing political landscape and emerging environmental concerns have led the emergence of new social conventions in terms of how farmers conduct themselves, e.g. at production stages of their livestock. It is important for farmers to be aware about which social conventions and rules are in force, how they are negotiated, and which individuals or groups have the power to influence their emergence.

\section{GENERAL LIVESTOCK PRODUCTION AND MARKETING CHALLENGES IN SA}

Motivations for keeping livestock vary in SA communal areas. In homesteads, cattle are used for practical support, including inter alia the provision of power for tilling soils, getting manure for cultivation and cooking fuel, providing skins for traditional clothing, horns, transport, milk, etc., food security, store of wealth, etc. These are economic contributions to livelihoods. But livestock are also used for other socio-cultural reasons including, spiritual sacrificial offerings at funerals, ancestral celebrations and worship, weddings, bride payments (lobola), community fines and taxes, events including circumcision ceremonies, and wealth display, etc. These varied uses mean that the production of cattle, for example, is not always aligned to producing high quality animals for the purpose of selling them off at different markets. In many cases cultural motivations lead to old cattle being sold at markets, which attracts lower prices (see Coetzee et al., 2005 and Musemwa et al, 2008).

Coetzee et al. (2005) reported that the poor condition of livestock often stems from lack of vaccination, and of good feed supplements as well as poor breeding practices leading to inferior genetics. These too contribute to poor prices the animals fetch at formal markets, either from speculators, auctioneers or butchers. This leads to low rates of concluded deals. It must be said that similar challenges are also observed at a regional level, for example in Botswana (Seleka \& Kebakile, 2017) as well as in Kenya as reported later. 


\subsection{Marketing related challenges}

Different marketing avenues are available to small farmers, but they are not all used, or even accessible, to the same degree. These include selling at public auctions, to brokers, abattoirs, butcheries and private individuals (informal markets), etc. Given the challenges already mentioned, informal markets are then highly used in most provinces. For example, in a survey in KwaZulu-Natal Province, Ndoro, Mudhara and Chimonyo (2015) reported that out of a total of 113 households, $49.6 \%$ sold privately, $34.5 \%$ used auctions and $14.2 \%$ used brokers. In much earlier periods, Nkosi and Kirsten (1993) similarly reported sales to butcheries at 57.9 $\%$, auctions at $28.8 \%$, speculators at $13.2 \%$, in the former homeland of Lebowa. Even when small farmers do participate in formal markets, they are not as successful because of lack of information on the required quality and quantity of products, market operations, auction calendars, etc. Their limited interactions with extension offices further contribute to lack of information (Coetzee et al, 2005; Musemwa et al., 2008; Ndoro, 2015; Mmbengwa, 2015).

Most studies agree that transaction cost issues are core to most challenges faced by small livestock farmers. Costs of transporting stock to and from markets are a barrier. Even with good roads, the costs of searching for good quality products by buyers are high. Ultimately these costs force farmers to adversely select themselves out of formal markets, which leaves them with limited prospects. This gap is a clear opportunity for extension offices to coordinate these information flows.

Many recommendations for improving this status quo focus on improving the work of government extension services (see Coetzee et al, 2005; Musemwa et al, 2008; Ndoro et el, 2015; etc.). For example, Coetzee et al. (2005: 98-99) concluded that "(the) small-scale livestock farming sector, specifically those involving cattle, presently experiences a strong desire for a well-structured extension support system that encompasses the marketing exposure of an otherwise dormant enterprise... These include concerted efforts to provide extension officers with the capacity, support and physical means to expose small-scale farmers to markets". Ndoro et al., (2015: 251) also concluded that "the custodians of livestock extension policy will have to devise platforms such as livestock shows and field days to facilitate the information of bonding and bridging social capital among key industry stakeholders. It is argued in this paper that the Meat Naturally Initiative (MNI) may present an effective model for how extension offices may do this work.

\section{PRODUCTION AND MARKETING IN SMALL SCALE LIVESTOCK IN KENYA}

Historically, Kenya's livestock marketing was supported by the Kenyan Meat Commission (KMC), which was established in 1950, but shut down in 1986, because of global competition ensuing from the economy's trade liberalisation (National Livestock Policy (NLP), 2008). This allowed livestock agriculture to be dominated by private players, especially in the marketing 
sphere, which led to an increased level of local producer abuse through unfavourable produce prices. However, a renewed interest in livestock and meat exports has led to the reoperationalisation of the commission with plans to set up satellite abattoirs along the northern livestock corridor and improvement of infrastructure for addressing international sanitary requirements for livestock and meat trade (Akliku, 2008). Nevertheless, the biggest demand for Kenyan meat production remains localised and comes from big urban centres like Nairobi, Mombasa, Eldoret, Kisumu, Nakuru, etc. Some of the demand is being met by livestock imports from neighbouring countries like Ethiopia, Somalia, Tanzania and South Sudan as depicted by bold arrows in Map one.

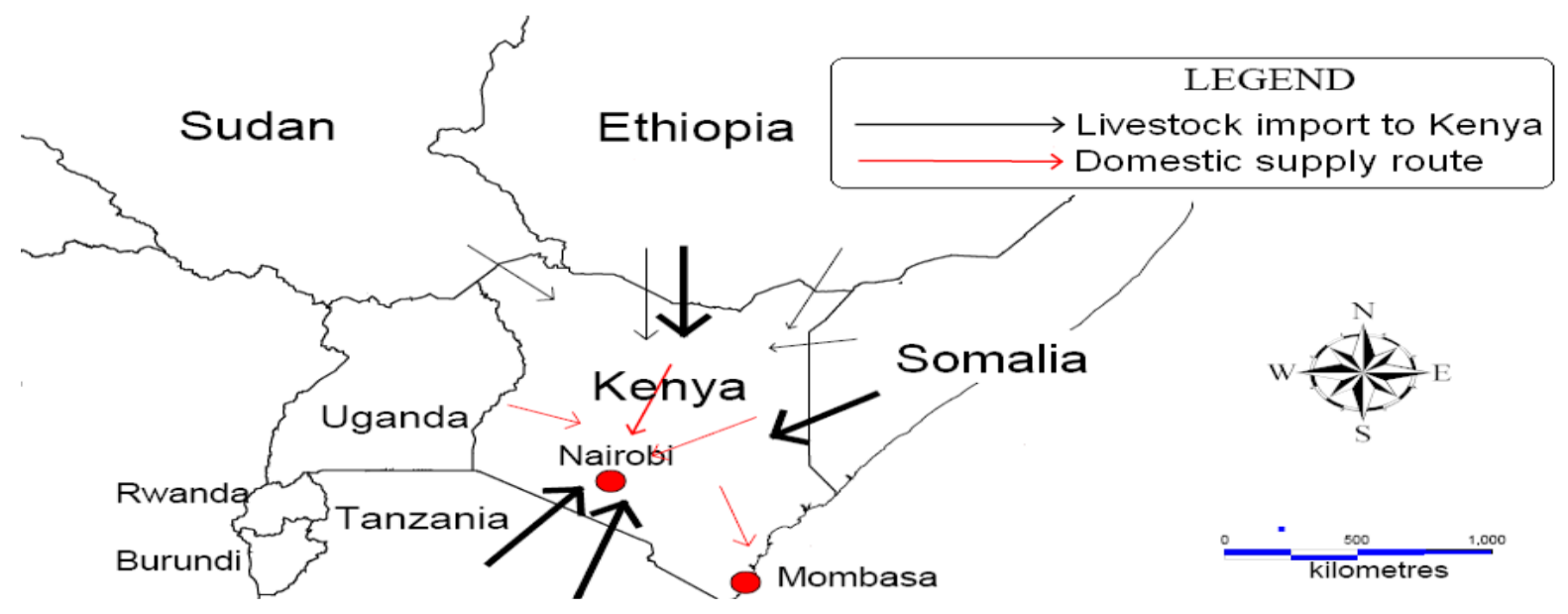

Map 1: Livestock trade internal and external routes

Source: AU/IBAR and NERPD (2006)

What makes Kenya's meat production and marketing industries primarily different from SA's are their greater inclusion of rural small producers located along the county's northern arid and semi-arid pastoral areas ${ }^{5}$. Pastoral areas contribute above $46 \%$ to beef meat, with the rest coming from commercial ranches. This means that the industries' operations and growth are important not just for GDP indicators but also for poverty alleviation and employment in remote poor areas of the country. Akliku (2002) reported that cattle production constituted more than 280000 tonnes to the total of 360000 tonnes of red meat. ${ }^{6}$ Even though other marketing channels exist for locally produced live cattle and beef meat, the most dominant marketing channel for small livestock was through auctions (see Serem, 1994, Akkliku, 2002, Akliku, 2008; Rakotoarisoa, Massawe, Mude, Ouma, Freeman, Bahiigwa \& Karugia, 2008). Compared to SA, this is a different picture, where communal small farmers are mostly excluded from such markets.

\footnotetext{
${ }^{5} 80 \%$ of Kenya's total land area

${ }^{6}$ The growth rate estimate of the beef production reported by Akliku (2002) of 15000 tonnes per annum would have predicted a slightly higher figure of 362000 tonnes for 2007 and just above 510000 tonnes for 2018 .
} 
Even though the participation of Kenyan small livestock farmers especially in marketing seems relatively impressive compared to that of SA, Kenyan beef producers have not historically enjoyed enough market power compared to other local players higher up in the value chains (e.g. brokers or butchers). This is presented historically in different microeconomic studies of the beef marketing sectors in various regions of the country. Serem (1994), reported big disparities in prices received by producers in the Baringo district compared to those received by traders, wholesalers and butchers for the same products. The patterns of disparities seem to have persisted over time as reported in other studies (e.g. Akliku, 2002 \& 2008, Rakotoarisa et al., 2008, Kenya National Bureau of Statistics (KNBS), 2018). Focussing on marketing activities and costs beyond animal sales by producers, the Baringo study (Serem, 1994) found that in about five terminal markets where beef products from Baringo district were sold, farmers were at the mercy of traders, butchers or brokers who controlled the markets through collusion to keep producer prices low. In the same study, the profits coming from price differences were calculated after taking account of costs of items related to local taxes, grading costs, abattoir fees, transportation, other logistics, etc. In turn, low prices affected negatively the participation rates of producers at auctions even in Kenya.

Akliku (2002) reported that innovating traders would typically operate in four distinct ways along cattle routes ${ }^{7}$ to terminal markets, namely:

a. Buy stock from source, transport and sell at terminal markets like Nairobi,

b. Buy stock from source, transport and sell at secondary destinations (e.g. ranches for fattening), before stock is further transported and sold at terminal markets,

c. Buy young stock at a third of the price, e.g. about 7000 KES in 2018 prices, keep for about two years, and resell at more than $20000 \mathrm{KES}$, and

d. Hire ranches to fatten cattle along trekking routes, at about $100 \mathrm{KES}$ per day per head in 2018 prices. These ranches would also be used as secondary destinations for young livestock.

Some traders use only one of these channels. Some use a combination of them depending on how well resourced they are and what levels of profit would accrue from each alternative. County and custom taxes were also be paid at different points, from places of origin, along routes and finally at terminal markets. ${ }^{8}$ An investigative committee of the Nairobi City County Assembly (NCCA, 2014) reported the following amounts being collected for different services from the City's abattoirs for the previous year.

Table 1 Government revenues from livestock services

\begin{tabular}{|l|l|l|}
\hline No & Item & Amount (KES) \\
\hline 1 & Meat Inspection & 13772315 \\
\hline 2 & Certificate of transport (all facilities) & 1355560 \\
\hline
\end{tabular}

\footnotetext{
734 livestock routes (16 active) for trekking were identified in Northern rangelands

8 There have also been reports of challenges of animal smuggling (e.g. from Tanzania) making it difficult to enforce health and financial requirements by officials.
} 


\begin{tabular}{|l|l|l|}
\hline 3 & Veterinary Health Certificate (export) & 1282000 \\
\hline 4 & Meat Transport permits (carriers and containers) & 100000 \\
\hline 5 & Licensing of abattoirs & 27000 \\
\hline Total & & 16536876 \\
\hline Total & $\mathbf{2 0 1 8}$ estimate @ (50\%) or 1.5 increase & $\mathbf{2 4 ~ 8 0 5 ~ 3 1 4}$ \\
\hline
\end{tabular}

Source: NCCA (2014)

Table 1 indicates the numerous barriers (logistics and costs) to trade for farmers, which stem from government agencies. Serem (1994) and Akliku (2002 \& 2008) presented the estimated profit making margins along the meat value chains from the farm gate to final consumers in 2018 prices in Table 2. These profits accrue to other stakeholders beyond the gates of the farming community.

Table 2 Profit making along beef value chain

\begin{tabular}{|l|l|l|l|}
\hline No & Stages & $@$ 2002 KES & @ 2018 KES \\
\hline 1 & Farm gate price of cattle & 10000 & 20000 \\
\hline 2 & Market price & 12500 & 25000 \\
\hline 3 & Cess certificate & 40 & 80 \\
\hline 4 & Transport & 1000 & 2000 \\
\hline 5 & Feed & 100 & 200 \\
\hline 6 & Labour & 100 & 200 \\
\hline 7 & Landing fee & 40 & 80 \\
\hline $\mathbf{8}$ & Profit made per animal by traders/brokers & $\mathbf{1 1 0 0}$ & $\mathbf{2} \mathbf{2 0 0}$ \\
\hline 9 & Standard grade per Kg & 110 & 220 \\
\hline 10 & Whole carcass (approx. 200Kg) & 22000 & 44000 \\
\hline 11 & Inspection & -100 & -200 \\
\hline 12 & Slaughter & -200 & -400 \\
\hline 13 & Revenue made by wholesale butchers per animal & $\mathbf{2 1 ~ 7 0 0}$ & $\mathbf{4 3 4 0 0}$ \\
\hline $\mathbf{1 4}$ & Profit made by wholesale butchers per animal & $\begin{array}{l}\mathbf{9 2 0 0} \\
\text { (line 10-line 2) }\end{array}$ & $\begin{array}{l}\mathbf{1 8} \mathbf{4 0 0} \\
\end{array}$ \\
& & & \\
\hline
\end{tabular}

Sources: Serem (1994); Akliku (2002 \& 2008) and NCCA (2014)

These estimated profit margins in Table 2 confirm the data from Serem (1994), who found capital returns of up to $108 \%$ accruing to traders.

\subsection{Auction markets in Uasin-Gishu county}

Even with the number of challenges identified throughout Kenya's beef value chains, the participation of smallholders in the beef industry remained relatively high throughout the country. In a 2018 visit to the Uasin-Gishu county (Rift Valley), farmers reported that auction markets for livestock (e.g. Cattle and Goats) were held at different locations (e.g. Cheptiret, Eldoret, Lemok, Ziwa, Matunda), once a week per location. At the Cheptiret auction in August 2018 , it was observed that more than two hundred cattle were brought to the market. One of 
the sellers ${ }^{9}$ reported that at Cheptiret the normal number of sellers was often between two and three hundred. The number of buyers was normally half the number of sellers.

The market opened at around $7 \mathrm{am}$ for registration of animals for sale with coordinators at two separate platforms. $100 \mathrm{KES}$ were paid per registered animal. The procedure for the auction had three distinct stages (See Figure 1). Firstly, buyers were given about two hours to inspect the livestock and negotiate prices directly with sellers. These negotiations resulted in sale agreements for a fraction (about 10 to $15 \%$ ) of total animals at the market. Secondly, the auction moved to its formal stage, where animals not sold during private negotiations were inspected by organisers for possible initial bidding prices. If prices were agreed upon, the animals were registered, numbered with a ticket issued accordingly, at a cost of $200 \mathrm{KES}$. Where agreements on initial prices were not reached the animals were removed. Thirdly, each registered animal was put on auction for the bidding process illustrated in Figure one.

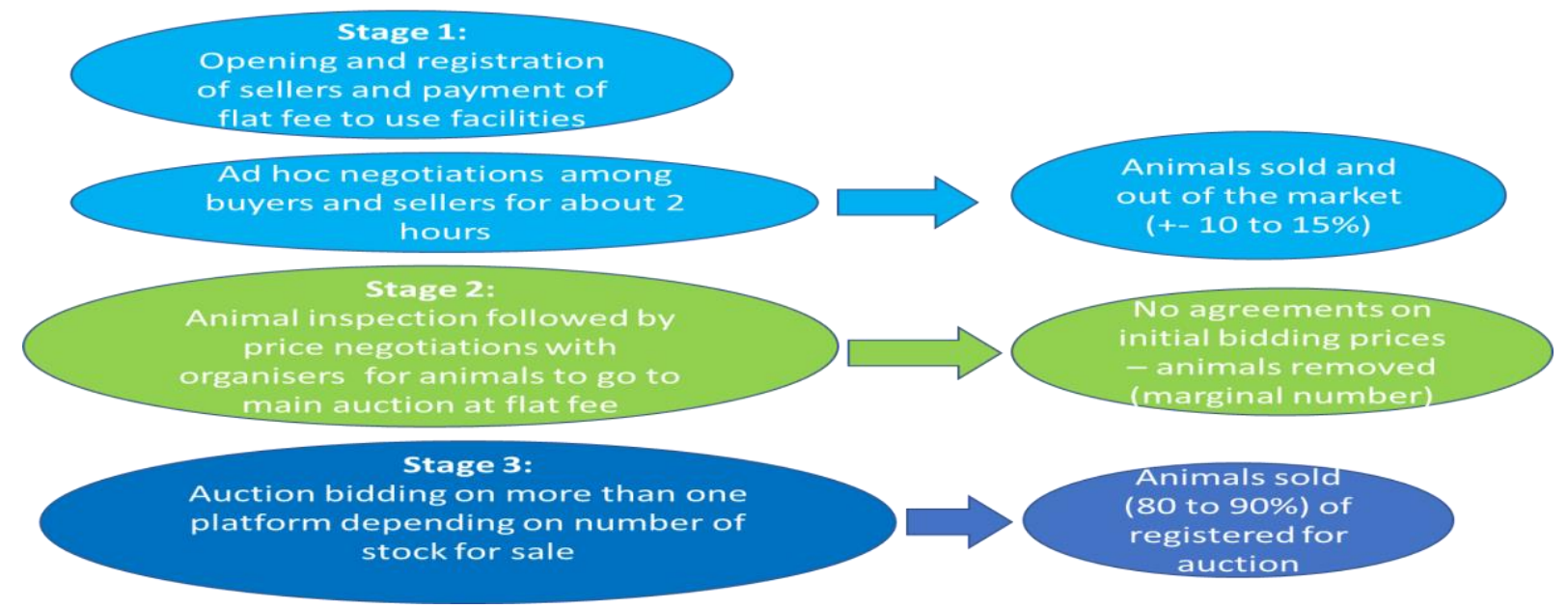

\section{Figure 1 The Typical Auction Market Stages (Uasin Gishu district, Kenya)}

On the day, more than two thirds of the animals brought to the market were sold during the bidding process. Sellers made higher profits on animals sold at prices higher than baseline prices. On average, a grown bull (e.g. $350 \mathrm{~kg}$ ) sold for more than $20000 \mathrm{KES}$. The animals were bought mainly for, a) resale at auction locations much further away from production areas, b) for slaughtering at butcheries, and c) for keeping and feeding to be resold at a later stage. No government official was present to check for any compliance documents and the animals were not branded nor rebranded after sale as was the case in SA auctions ${ }^{10}$.

\section{THE MEAT NATURALLY INITIATIVE (MNI) CASE IN THE ECP}

In the Eastern Cape Province of SA a rangeland restoration project was found and documented. This project organised livestock auction markets for rural small farmers as one of

\footnotetext{
${ }^{9}$ From Maileunne near Eldoret

${ }^{10} \mathrm{Mr}$ M. Kipkemoi reported that the branding exercise was mostly performed in areas along the borders where cases of animal theft were common.
} 
its holistic developmental initiatives to incentivise farmers to participate in environmental protection efforts (ERS, 2016:3). The holistic approach accounted for more than just transaction and information costs as barriers to resolving socio-economic issues faced by SA small farmers located in communal areas. Put simply, stakeholders work with traditional leaders to mobilise community members to restore and protect their ecological capital. The model rewards community members with economic incentives aimed at reducing poverty and improving their livelihoods, through participation in livestock-based enterprises. Theoretically, efforts at restoring and protecting the natural environment are rewarded with increased educational opportunities, administrative services to get livestock vaccinated, registered and branded as well as market based economic benefits, etc. For example, mobile livestock auctions are organised and brought directly to communities, which reduces the transaction costs. Different commission rates for selling stock are charged to members with different records of participation in environmental restoration and protection efforts. Higher levels of participation are rewarded with lower rates. Since the first reported auction held in 2014, some communities now pay a $3 \%$ commission, as opposed to the normal $6 \%$ in the region. The model also accounts for change in the natural and socio-political environments, skills requirements, self-governance and monitoring by members, recognition and reinforcement of supportive traditional systems, livelihoods, as depicted in Figure two.

\section{Meat Naturally Sustainability Model Outline}
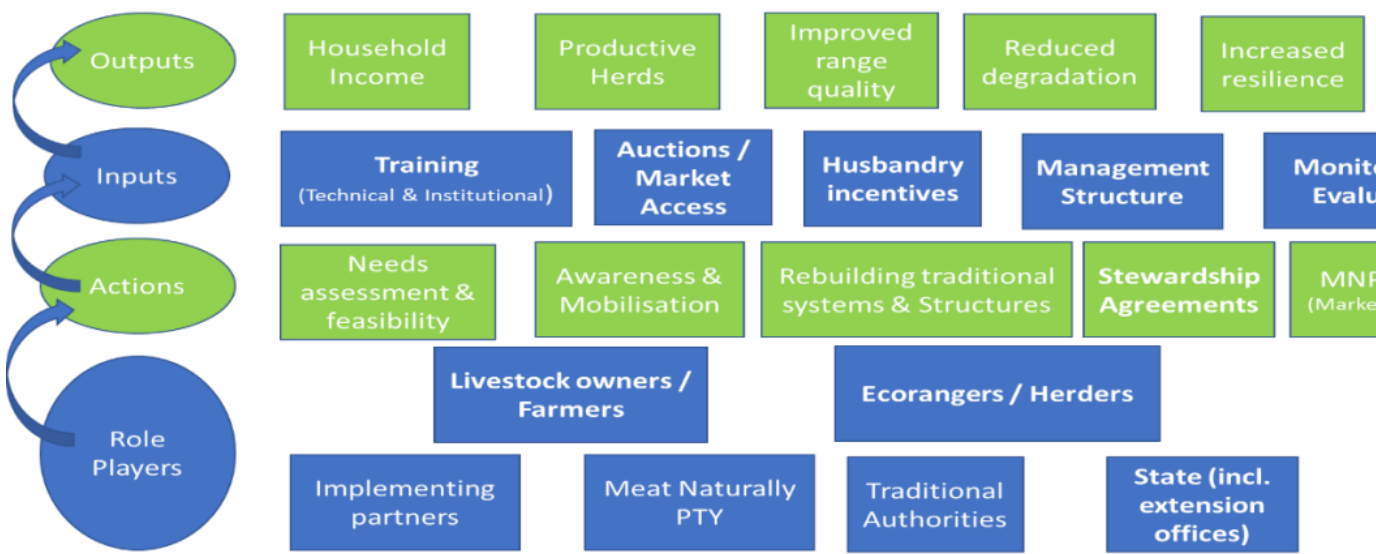

incentives

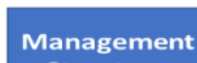

Structure

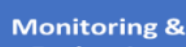

Evaluation

Figure 2 Outline of Key Model Content and Process

Source: Environmental Rural Solutions (ERS, 2016)

The sustainability of this model relies on cooperation and participation of players to achieve all its outputs. As illustrated, some of the inputs identified act as incentives for players like farmers and rangers to participate, e.g. training opportunities provided to eco-rangers by facilitators and market access provided to farmers by Meat Naturally Pty (MNP). Community agreements are put in place for monitoring and evaluation by members and agents. These assist in determining the level of benefits to members given their level of compliance (McLeod, 2019). During the 2019 field visit, the model was almost fully operational in many of the 
villages $^{11}$ in the Umzimvubu Catchment, with the first auction executed in $2014^{12}$. The reported successes have however not been without challenges as observed in the field and reports ${ }^{13}$. For example, different villages were at different stages of implementing the model and received different commission rates per livestock sale. Not all stakeholders were participating fully as required by the model. For example, the extension office, which was supposed to be one of the key players was not fully onboard ${ }^{14}$. Nevertheless, given the relative success of the approach in SA with respect to improved market participation of small rural farmers, it is appropriate to present the model for its potential lessons for broader SA and even for Kenya. From the way in which small farmers (as opposed to established farmers ${ }^{15}$ ) are supported through the project and its auction market initiative, potential lessons for some of the work of extension offices in SA can be identified.

\subsection{The MNP auction process}

Before the first auction of 2019 was held Nel (2019) explained that in 2018 the average price of units sold at the MNP auctions was R6 500, although good animals sold for as high as R15 000. The weight and physical conditions of an animal determined its price. Best prices were obtained around autumn, where fully grown animals' average weight was $400 \mathrm{~kg}$, after winter it was around $320 \mathrm{~kg}$. In the same year, more than 2400 cattle were sold through the project at a total value of R15,3 million from 1168 sellers at more than 20 mobile auctions in different villages. The conversion rate was $90 \%$, just slightly higher than the rate in Uasin-Gishu district of Kenya. Overall, most animals sold were Grade B, and this excluded demand from high end markets, such as Woolworths stores (see Appendix for the 2014-218 stats). Like in the Kenyan case, most animals sold would end up in nearby abattoirs ${ }^{16}$, local butcheries and on farms for further fattening.

\footnotetext{
${ }^{11}$ McCloed (2019) reported that environmental projects were being undertaken in more than 50 villages.

${ }^{12}$ Villagers in Makhoba reported that there were three main locations in the region where auction markets were being held (Makhoba, Underberg and Cederville).

${ }^{13} \mathrm{Nel}$ (2019) of Meat Naturally Pty reported that the development of accurate estimation models for financial benefits accruing to communities from reducing erosion, removing invasive alien vegetation with related water saving benefits was still underway. There are reported issues relating to self-monitoring and community leadership, where claims have been made of some community leaders (e.g. Chiefs) treating different members differently (McCloed, 2019). This is a potential threat to the overall sustainability of the project if social conflicts escalated stemming from such discrimination in governing communal areas (Ostrom, 1992).

${ }^{14}$ In fact, McCloed (2019) reported that at auction market specifically the most visible State representatives are the police, who come to ensure administration compliance from villagers. Although appreciated, the detail in requirements to comply by sellers seem to change from one auction to the next. At an auction held on the $19^{\text {th }}$ January 2019 In Makhoba village, an additional requirement for sellers, not related in time, was to carry a letter from stock owners authorising selling persons (if not the owner) in addition to carrying the national Identity Document (ID) and stock registration certificates. For older and uneducated stock owners not able to read or write this requirement was a challenge limiting their participation.

${ }^{15}$ For example, Farmers Livestock Agents operating in Cedarville, Underberg, Kokstand, Swartberg, Richmond, Ixopo and Mooiriver had a schedule of one auction markets per month in each of the following towns; Underberg, Cedarville, Swartberg and Kokstad (i.e. 48 scheduled auctions per year). This was in addition to 13 special meat sales with the highest frequency of sales in August and November. See participation list of commercial farmers' auction held on the $12^{\text {th }}$ February 2019 in Cederville (see Appendix)

${ }^{16}$ The ECP had the highest number of cattle (over 3 million) (Redmeat SA, online) and second highest number of abattoirs in the country (Safiri, online)
} 
Before the auction day, negotiations would be undertaken with relevant community leaders to determine an auction date and mobilise potential sellers and buyers by facilitators (e.g. ERS), local committees, and market access organisers (MNP). ERS would ensure that potential sellers have their cattle registered and ready for sale (McCloed, 2019). From a business feasibility perspective, a minimum of 70 cattle needed to be sold for the auction to be viable (Nel, 2019). Before the January 2019 auction, concerns were raised that not many villagers had indicated they would participate as sellers.

Nevertheless, the auction went ahead on 19 January 2019 in Makhoba village (northern ECP) ${ }^{17}$. Organisers set up platforms and ramps around 06:30 am. The auction process seemed much simpler and better organised in terms of physical infrastructure compared to Uasin-Gishu. Only two distinct stages in the auction process were identified. Firstly, registration documents for cattle from sellers were inspected by the police and organisers for compliance, before animals were allowed into a holding cell. From the cell, each animal would then be brought onto a weighing scale, its weight and physical attributes announced on a loud-speaker for the bidding process to commence. The animal would be sold if the seller was happy. Secondly, if the seller was not happy with the final price, negotiations between the seller and final bidder could take place, often leading to agreements on a different price or there was no-sale. Sale prices ranged from R2000 for calves to R8600 for a 544kg steer. After a while, one could estimate that for a $400 \mathrm{~kg}$ animal the initial bidding price would be about R5000 and the final selling price would be around R7000. The auction lasted between 2 and 3 hours. A total of 46 animals were put on sale, the average price at this January auction was around R5500, lower than the reported 2018 average of R6500. The spectators, many of whom were stock owners, complained about the low prices at this auction. They mentioned that anybody selling at this time of the year was probably desperate for immediate cash.

Afterwards, organisers mentioned that animals that would normally sell for R12 000 sold for $\mathrm{R} 8000$, and the auction may have been a loss, because only $66 \%$ of the required minimum number of animals were put on sale (i.e. 46 of 70). Additionally, because of low prices, only 38 animals were sold, which meant that the conversion rate was $82.6 \%$, lower than the normal 2018 rate of $90 \%$. Community members indicated that they were targeting auctions in the month of April ${ }^{18}$ to make more money when prices are expected to be high. This would explain why the number of sellers was low. The lower prices were most likely also influenced by a very low number of buyers, with only two being the most active. This was very low compared to Uasin-Gishu auctions. The buyers were the biggest winners on the day. With 38 units sold, at an average price of R5500, a revenue of R209 000 was made. At 5\% commission rate, organisers would receive R10 450 to cover their $\operatorname{costs}^{19}$, instead of a minimum of R22 750 for a minimum of 70 units sold at R6500 on average. If this was the norm, it would be a serious

\footnotetext{
${ }^{17}$ This is the $2^{\text {nd }}$ auction market held at this location. Eco-compliance is still low and sellers receive a commission rate of only $5 \%$ as opposed to the normal $6 \%$ in the region.

18 A time for religious holidays

${ }^{19}$ Additional services at a cost they provided included providing transport to buyers
} 
threat to the model's overall sustainability. ${ }^{20}$ However, the next auction held in March 2019 was a greater success, with a higher number of buyers and more animals sold at higher prices. 21

\section{COMPARATIVE DISCUSSION AND SOME RECOMMENDATIONS}

Using thematic mapping of identifying the number of times an issue surfaced, the overall differences and similarities between Kenyan and SA livestock agriculture can be discussed within several institutional themes (Saleth, 2004). The themes include, a) evolution of rules and traditions (geopolitical production patterns and governance issues), b) market competition issues, c) power bargaining (socio-political patterns), d) physical infrastructure and external support (see Table 3). In some cases, the issues overlapped more than one theme.

Table 3 Thematic issues from surveys

\begin{tabular}{|l|l|l|l|l|}
\hline Theme & Evolution of rules & Power bargaining & Competition & Infrastructure \& support \\
\hline $\begin{array}{l}\text { Frequency of } \\
\text { issues }\end{array}$ & 18 & 12 & 10 & 3 \\
\hline
\end{tabular}

Of 31 issues identified in total in the thematic analysis across SA and Kenya, most issues (18) could be classified under the evolution of rules and traditions. These were followed by issues under the bargaining powers of stakeholders (12), followed by those under market competition (10). Fewer issues were related to physical infrastructure and external support (3).

\subsection{Evolution of rules and traditions}

From the data, the rules, traditions and norms that govern how stakeholders in livestock agriculture behave have many similarities between SA and Kenya. In some cases, the traditions apply only to some or all players within a sector (e.g. producers, sellers, buyers, coordinators). In other cases, they apply only to supporting players (e.g. government agencies).

While traditional uses of livestock (e.g. store of wealth, spiritual ceremonies, bride payments) among SA small farmers seem to overlap with especially those of nomadic communities in Kenya (e.g. the uses of stock by the Maasai people) the extents to which these traditional uses are prevalent in the two countries also differ. The difference in extent may have had a strong impact on the different levels of participation in formal business markets of small farmers in

\footnotetext{
${ }^{20}$ But given that one of the objectives of the model's is to reduce poverty it would be difficult to motivate not to organising the January auction when some community members are most stranded.

In comparison, at a commercial auction on 12 February 2019, for mainly established farmers in Cederville three hundred and sixty (360) animals were brought on auction by 48 farmers/sellers. Of the total animals, $260(72 \%)$ came from 19 (39\%) White commercial farmers. Only 50 animals (14\%) came from only 4 Black commercial farmers. The remainder of cattle came from 23 emerging Black farmers (Appendix). At this auction, a bit later in the year, prices were higher, about $\mathrm{R} 21 / \mathrm{Kg}$ (compared to $\mathrm{R} 18.5 / \mathrm{kg}$ ) and the conversion rate was also higher at more than $90 \%$.
} 
the two countries. Traditional considerations in the use of livestock in SA seems to have a bigger negative impact on their preparedness for business participations. For SA, it was reported that even though communal farmers own more than a third of total livestock population, their auction market participation was only at $10 \%$, while in Kenya auctions are the main channel of livestock marketing for small farmers who supply beef to more than $70 \%$ of the country's demand. The prevalence of traditional uses of livestock in SA could also be linked to stronger traditional leadership systems, which have constitutional protection. In the MNI project, traditional authority also features as one of key role players in the model.

This list, description and extent of issues provides a useful framework for South African extension offices to use when engaging communities if they were in the position of coordinators of a similar support structure to rural farmers in other provinces.

\subsection{Market competition and bargaining powers}

General market exclusion is different in the two countries. While small farmers in SA are generally more excluded in formal markets than in Kenya, the market power of all small farmers is marginal in both countries. The Kenyan beef value chains are dominated by brokers, traders and butchers. There are persistent reports of high levels of collusion by fewer brokers, especially in the marketing stages of livestock. Even though the market domination by brokers is higher in Kenya compared to SA, Kenyan farmers are still better off. In SA small farmers are almost completely excluded in the marketing stages of red meat, where big suppliers dominate the market (RedmeatSA, 2017). Historically, farmers in Kenya have received depressed prices, while high profits accrue to traders, especially butchers as illustrated in Table 2. As the small farmer markets develop in SA it should be anticipated that brokers would emerge to occupy many spaces where obvious profits ${ }^{22}$ can be made and market issues like those observed in Kenya may develop, where market powers and prices are skewed against producers. This means extension offices in SA must already develop strategies for bypassing any potential dominance of markets by traders to the abuse of farmers through prices in different regions of the country. The possibilities include the use of mobile auction platforms to reduce transport and other logistical or infrastructural costs to farmers as illustrated by the MNP case. In the near future, the possible use by small farmers of online marketing platforms in SA should get attention now. Such online platforms have proven quite useful in crop markets in Kenya (Mbatha, 2019).

\subsection{Power bargaining among different stakeholders}

In the MNI case, traditional leaders, buyers, auction organisers, government agencies, farmers, etc., are all key stakeholders in the overall success of the ecological project in the ECP. Striking a power balance with as many stakeholders is more difficult. The stakeholders also do not have

\footnotetext{
${ }^{22}$ At an average price of R 70 / kg of beef in SA a carcass weighing $250 \mathrm{~kg}$ would sell for R 17500 (Flashmeat, 2019), with returns of more than $200 \%$ for auction price of R 6500
} 
the same negotiating powers with respect to how different aspects of the project should run (including market access incentives). When power can easily be abused by some of the players with negative impacts on other stakeholders the system becomes vulnerable. It is therefore important to put in place monitoring systems that are agreed upon by all members (Ostrom, 1992). The monitoring of environmental restoration in each village has been key in the success of the MNI. This is a lesson for other coordinators of developmental projects in other areas. For extension services, the monitoring would have to ensure that records are kept and evaluated, for example on how each of the small farmers benefit overtime from government support initiatives like mobile auctions to limit abuse from power bargaining in communities.

\subsection{Specific features of auctions in Uasin-Gushu district versus MNP auctions}

The organisational structure of auctions in Kenya was more complex with at least three stages (refer Figure 1) where farmers can improve the likelihood of their animals getting sold. This three-stage structure could be considered for general adoption in SA to improve the participation and conversion rates. The MNP auctions were not only aimed at income generation, but they also acted as incentives to restore and protect the rangelands. Outside the MNI project, however, livestock auctions in both countries had the profit motive as the main objective.

While auction organisers in SA used the commission rate for payment ${ }^{23}$ to generate money, a flat rate payment was used in Kenya ${ }^{24}$. In the MNI project where environmental protection was the main goal, the rate paid by farmers varied given the different commission percentages ${ }^{25}$ that are paid by different villages based on the level of their participation in environmental initiatives. One of the benefits of using a commission rate is that organisers benefit directly when animals sell at higher prices and would therefore want to run markets that attract higher prices. Although farmers also benefit when animals sell at higher prices, they always benefit more if they can sell at a higher price using a flat rate. For a collective project, however, where cooperation is key, a commission rate seems more practical. Given the predominance of communal or collective land ownership or access in most SA rural areas, using adopting a commission rate in similar projects in other parts of SA would be more sensible.

Overall, it appears that in both countries traditional systems have kept the right (and means) to cattle ownership as a male prerogative. In a survey of Kenya's Kilifi district for example, 84.2\% of farmers were male (Mbatha, 2019). In SA, land use and ownership rights, especially in traditional areas is also male dominated even though a high number of women are also small farmers (Moneyweb, 2018). There were also big gender disparities among auction buyers and sellers in both countries. Sadly, the gender equity problem in both countries seems to require solutions beyond just the scope of one government department or project given that it is a

\footnotetext{
${ }^{23} 6 \%$ is the normal commission rate

${ }^{24} 100$ KES for participating at markets and 200 KES per animal sold in 2018

${ }^{25}$ Starting at $5 \%$, going down to $3 \%$ per environmental protection effort
} 
deeply institutionalised issue. Nevertheless, it was observed that at all auction markets in the ECP and in Kenya, food traders were set up shop for buyers and sellers. The food traders were mostly women. Going forward they should be supported deliberately given that such trade contributes positively to efforts aimed at poverty alleviation.

\section{SUMMARY AND CONCLUDING REMARKS}

There are positive and negative lessons from each country case. In terms of business operations, SA small communal farmers in general seem to lack many of the prerequisite elements that make for innovative competitive markets. Many SA small farmers are still operating within mainly traditional systems with respect to livestock farming. A higher number of these farmers remain excluded from different parts of the value chains of formal beef markets compared to Kenya and even though they own large herds of cattle, their contribution to the country's demand for beef remains marginal. On the other hand, the conceptual design of the MNP case seems more advanced with respect to its holistic consideration of key environmental issues alongside social and economic matters. The approach to business of the model seems more sustainable if implemented as intended in its design. However, only a small proportion of small farmers in the Northern ECP benefit currently from this MNI model. Many parts of the project and its approach to development needs to be emulated for the benefits of more SA small farmers in other rural regions. It is argued in this study that extension offices would play the required role in coordinating the implementation of some version of the model depending on the local contexts. If the useful lessons from the ECP model are not deliberately spread across the country, as small farmer markets develop on their own, many of the bad structural elements of such markets may creep in. The Kenyan study illustrates well what some of these elements could be with respect to potentially rising farmer abuses by traders or brokers.

\section{REFERENCES}

AKLIKU, Y., 2002. An audit of the livestock marketing system in Kenya, Ethiopia and Sudan, AU-IBAR Bulletin Volume 1 Nairobi, Kenya

AKLIKU, Y,. 2008. Livestock Marketing in Kenya and Ethiopia: a review of policies and practice. Feinstein International Center (FIC) Report. Addis Ababa, Ethiopia

COASE R., 1998. The New Institutional Economics. The American Economic Review., 88 (2):72-74

COASE R., 1960. The Problem of social cost. Journal of Law and Economics., 3:1-44

COETZEE L., MONTSHWE B.D. \& JOOSTE A., 2005. The marketing of livestock on communal lands in the ECP: Constraints, challenges and implications for the extension services. S. Afri. J. Agric. Ext., 34(1): 81-103 
ERS, 2016. Sustainability model for supplying meat naturally. Environmental Rural Solutions. Available from https://umzimvubu.files.wordpress.com/2014/10/meat-naturallysustainability-model-final-31102016.pdf

FARMERS LIVESTOCK AGENTS, 2019. Participation register for 17 February 2019. Public Notice. Cederville, SA

FLASHMEAT, 2019. Price list as at 30 January 2019. Flashmeat distributors. Available online at http://www.flashmeat.co.za/downloads/flashmeat_pricelist.pdf [accessed February 2019]

HODGSON G. M., 1998. The Approach of Institutional Economics. Journal of Economic literature. 36(1): 341-350

HODGSON G.M., 2006. What are Institutions? Journal of Economic Issues., XL(1):1-25

JOOSTE A., 1996. Regional trade of beef in southern Africa. MSc Thesis, University of Pretoria

JOOSTE A., 2001. Economic implications of trade liberalisation on the SA red meat industry. PhD Thesis, University of the Free State

KNBS, 2018. Quarterly Gross Domestic Product Report. Kenya National Bureau of Statistics. Available from https://www.knbs.or.ke/quarterly-gross-domestic-product-reportsecond-quarter-2018/

KING A.N., 1985. Agriculture: An introduction for Southern Africa. Cambridge University Press, Cambridge

MBATHA C.N., 2019. Diversification in Production and Marketing Strategies for Higher Returns on Farmlands Located in a Coastal and Tourist District of Kenya: Lessons for South Africa's Land Reform Projects in Similar Locations. African Journal for Tourism and Leisure (AJHTL) 9(1): 1-19

MCLEOD. N., 2019. Personal communication January 2019. Manager, Environmental Rural Solutions (ERS), Umzimvubu Catchment Area, Eastern Cape Province, SA

MMBENGWA, V.M., NYHONDO, B., LINDIKAYA, M., NGETHU, X. \& VAN SCHALKWYK, H., 2015. Communal livestock farming in SA. Does this farming system create jobs for poverty stricken rural areas? SYLWAN, 159 (10):176-192

MUSEMWA L., MUSHUNJE A., CHIMONYO, M., FRASER G., MAPIYE C. \& MUCHENJE V.. 2008. Nguni cattle marketing constraints and opportunities in the communal areas of SA: Review. African Journal of Agricultural Research 3 (4): 239245

NEL, G., 2019. Personal communication. General Manager Meat Naturally (Pty) Ltd. Cerderville, Eastern Cape Province, SA 
NLP, 2008. National Livestock Policy. Session Paper 2 of 2008. Republic of Kenya Ministry of Livestock Development, Nairobi, Kenya

NDORO J.T., MUDHARA M. \& D CHIMONYO M., 2015. Farmers' choice of cattle marketing channels under transaction cost in rural SA: a multinomial logit model. African Journal of Range \& Forage Science, 32(4):243-252

NKOSI S. A. \& KIRSTEN J. F., 1993. The marketing of livestock in SA's developing areas: a case study of the role of speculators, auctioneers, butchers and private buyers in Lebowa. Agrekon, 32(4) 230-237

NORTH D. C., 1990. Institutions, Institutional Change, and Economic Performance. Cambridge University Press, Cambridge, MA

NORTH D.C., 1991. Institutions. Journal of Economic Perspectives, 5(1): 97-111

NORTH D.C., 1992. The New Institutional Economics and Development. American Economist. Spring:3-6

OOSTHUIZEN, L.K., MEIRING, J.A., BOTHA, P.W., GROVE, B., MONKHEI, M.M., \& PRETORIUS I., 2005. Cost Estimating Procedures for Micro, Drip and Furrow Irrigation Systems as well as Economic Analyses of the Relevant Irrigation Systems for Large and Small Scale Farmers in the Onderberg/Nkomazi Region. Report to the Water Research Commission by the Department of Agricultural Economics, University of the Orange Free State. Paper no 974/1/05

OSTROM, E., 1990. Governing the Commons: The Evolution of Institutions for Collective Action: Political Economy of Institutions and Decisions. Cambridge University Press, New York

OSTROM, E., 1992. Crafting Institutions for Self-Governing Irrigation Systems. ICS Press, SA Francisco

QUIGGIN, J., 1988. Private and Common Property Rights in the Economics of the Environment. Journal of Economics. 22(4):1071-1087

RAKOTOARISOA, M., MASSAWE, S., MUDE A., OUMA, R., FREEMAN, A., BAHIIGWA, G. \& KARUGIA J. 2008. Investment Opportunities for Livestock in the North Eastern Province of Kenya. A Synthesis of Existing Knowledge. ReSAKSS Working Paper No. 12. Nairobi, Kenya

REDMEATSA, 2017. AMT Beef outlook/review February 2017: Red meat industry forum. Available from http://www.redmeatsa.co.za/wp-content/uploads/2017/03/AMT-BeefOutlook-February-2017.pdf

SAFIRI, 2019. Meat and fish processing and distribution. Available from https://www.safiri.co.za/ec/meat_\&_fish_processing_\&_distribution.html 
SALETH, R.M. 2004. Understanding Water Institutions: Structure, Environment, and Change Process. Paper presented at The Water Management for Local Development Conference. Loskop Dam, SA.

SELEKA, T.B. \& KEBAKILE P.G., 2017. Export competitiveness of Botswana's beef industry. The International Trade Journal, 31(1):76-101

SEREM, A.K., 1994. Beef cattle marketing in Baringo district, Kenya. An MSc Thesis. University of Nairobi, Kenya

VAN KOPPEN, B., TAPELA, B. N. \& MAPEDZA E., 2018. Joint ventures in the Flag Boshielo Irrigation Scheme, SA: A history of smallholders, states and business. IWMI Research Report 171. Colombo, Sri Lanka

WILBER, C.K \& HARRISON, R.S., 1978. The Methodological Basis of Institutional Economics: Pattern Model, Storytelling, and Holism. Journal of Economic Issues., XII(1): 61-89 